\title{
Cotton fiber quality affected by water availability and silicon application
}

Raiana Crepaldi de Faria Nocchi ${ }^{1}$, Gustavo Soares Wenneck ${ }^{1}$, Roberto Rezende ${ }^{1}$, Enes Furlani Junior ${ }^{2}$, Vinícius Villa e Vila ${ }^{1}$, Noemi Cristina de Souza Vieira ${ }^{2}$, Amanda Pereira Paixão $^{2}$, Reni Saath ${ }^{1}$

${ }^{1}$ Universidade Estadual de Maringá - UEM, PR. ${ }^{2}$ Universidade Estadual Paulista - UNESP, SP. E-mail: gustavowenneck@gmail.com

\begin{abstract}
The quality of cotton fiber is a fundamental criterion for determining the commercial value of the product, being influenced by the conditions of cultivation. The study aimed to evaluate irrigated and non-irrigated cultivation systems and the management of silicon fertilization on cotton fiber characteristics. The experiment was carried out in the field in Selvíria-MS, in the 2017/2018 agricultural crop. It was adopted a randomized block design, in a $2 \times 6$ factorial scheme, with two cultivation conditions (irrigated and rainfed) and six doses of $\mathrm{Si}\left(0,50,100,150,200\right.$ and $\left.400 \mathrm{~g} \mathrm{ha}^{-1}\right)$, with four replications. Seeds of the genotype TMG 11 WS were used. Irrigation was carried out with sprinklers spaced at $6 \times 6 \mathrm{~m}$. The application of Si via leaf was carried out at 50 and 70 days after emergence. From the cotton fiber, the characteristics of length, micronaire, strength, uniformity, elongation, reflectance, yellowing, degree of leaves, impurity and impurity particles were analyzed. The data submitted to analysis of variance by the $F$ test, the means compared for the cultivation condition, and regression analysis for the amount of Si. The cotton fiber in irrigated cultivation showed improvement in the characteristics resistance, reflectance and yellowing. The application of Si via leaf reduced the leaf grade in the cotton fibers.
\end{abstract}

Keywords: Beneficial element; Gossypium hirsutum; irrigation.

\section{Qualidade da fibra de algodão afetada pela disponibilidade de água e aplicação de silício}

\section{Resumo}

A qualidade da fibra do algodão é critério fundamental para determinação do valor comercial do produto, sendo influenciado pelas condições de cultivo. O estudo teve como objetivo avaliar sistemas de cultivo irrigado e não irrigado e o manejo da adubação de silício sobre características da fibra do algodão. 0 experimento foi desenvolvido a campo no município de Selvíria-MS, na safra 2017/2018. Foi adotado delineamento em blocos ao acaso, em esquema fatorial $2 \times 6$, sendo duas condições de cultivo (irrigado e sequeiro) e seis doses de $\mathrm{Si}\left(0,50,100,150,200\right.$ e $\left.400 \mathrm{~g} \mathrm{ha}^{-1}\right)$, com quatro repetições. Foi utilizado sementes do genótipo TMG 11 WS. A irrigação foi realizada com aspersores espaçados em $6 \times 6 \mathrm{~m}$. A aplicação de Si via foliar foi realizado aos 50 e 70 dias após a emergência. A partir da fibra do algodão, foram analisadas as características de comprimento, micronaire, resistência, uniformidade, alongamento, reflectância, amarelecimento, graus de folhas, impureza e partículas de impureza. Os dados submetidos a análise de variância pelo teste $F$, as médias comparadas para a condição de cultivo, e análise de regressão para quantidade de Si. A fibra de algodão em cultivo irrigado apresentou melhoria nas características de resistência, reflectância e amarelamento. A aplicação de Si via foliar reduziu o grau de folhas nas fibras de algodão.

Palavras-chave: Elemento benéfico; Gossypium hirsutum; irrigação.

\section{Introduction}

The cotton crop (Gossypium hirsutum L.) has great economic importance worldwide. Brazil stands out among producers for its current production and the potential for expansion in area and yield (SEVERINO et al., 2019). This 
visibility is related to the researchers conducted to analyze the productive viability in different regions, cultivars and in the selection of genetic materials (ALMEIDA et al., 2017; BONIFÁCIO et al., 2015; LIMA et al., 2018). Brazilian product presents a trend towards the international market (CAVALCANTE; TANNÚS, 2020).

The management of the crop expresses direct effects on yield and on the final quality of the product, which is mainly destined for the textile industry (SEVERINO et al., 2019). The adoption of practices that combine the production increase and increase the efficiency of resource use is fundamental for the production system. Water management is among techniques with a direct impact on cotton yield and quality (LIMA et al., 2018; ZONTA et al., 2015).

The presence of water deficit in critical periods for crop can affect the production components, with a decrease in yield varying according to the deficit level, edaphoclimatic and genetic conditions (LIMA et al., 2018; ALMEIDA et al., 2017; ZONTA et al., 2015; COUTINHO et al., 2015). In this sense, crop irrigation can be fundamental for productive success and economic return, mainly due to insufficient rainfall exclusion for the plant's demand (SANTOS et al., 2018).

In addition to water management, the use of beneficial elements can mitigate adverse effects during cultivation (MALAVOLTA, 2006).
Silicon is not considered an essential element, but a beneficial element that can favor the development of plants under unfavorable conditions, improve phytosanitary aspects and crop yield (ALCANTRA et al., 2019; FERRAZ et al., 2017; GAMA et al., 2016; WENNECK et al., 2021). Productive characteristics reflect on the quality of the product, and consequently on the commercialization value (MORAIS et al., 2021), the adoption of techniques and management that maintain or improve the commercial quality of the product under unfavorable growing conditions has the possibility of increasing productive efficiency and yield.

The aim of the study was to analyze the technological quality of cotton fibers, grown under different conditions of water availability, silicon applications and the interaction of factors.

\section{Material and Methods}

The study was developed in the experimental area of the Faculty of Engineering of Ilha Solteira-UNESP, located at latitude 200 22'S, longitude 51ㅇ 22' and altitude of $335 \mathrm{~m}$, in Selvíria-MS, in the 2017/2018 agricultural crop. The average annual precipitation is $1370 \mathrm{~mm}$, and the average annual temperature is $23.5^{\circ} \mathrm{C}$ (FEIS/UNESP, 2021). Table 1 refers to monthly precipitation and temperature data.

Table 1. Climatic data from December 2017 to May 2018 in the experimental area, Selvíria-MS.

Period of the year $\quad$ Accumulated precipitation $(\mathrm{mm})$

Average temperature $\left({ }^{\circ} \mathrm{C}\right)$

$\begin{array}{ccc}\text { December/2017 } & 263.2 & 25.3 \\ \text { January/2018 } & 258.4 & 25.5 \\ \text { February/2018 } & 96.9 & 25.0 \\ \text { March/2018 } & 52.3 & 27.6 \\ \text { April/2018 } & 87.0 & 25.2 \\ \text { May/2018 } & 8.3 & 24.8\end{array}$

Source: FEIS/UNESP, 2021

The experiment was carried out in randomized blocks, in a 2x6 factorial scheme, with two growing conditions (irrigated and not irrigated) and six doses of Si (0, 50, 100, 150, 200 and $400 \mathrm{~g} \mathrm{ha}^{-1}$ ), with four replications per treatment. To define application doses (treatments), it was considered according to responses to different cultivars obtained by Ferraz (2012).The experimental plots consisted of eight rows (4 m long) spaced $0.9 \mathrm{~m}$ apart, with the four central rows being considered as the useful area.

The soil is classified as LATOSSOLO VERMELHO Distrófico, correlated with Oxisoils (SANTOS et al., 2018) the soil has a very clayey texture $(67 \%$ of clay) and the chemical characteristics in the depth of $0.2 \mathrm{~m}$ were: $\mathrm{pH}$ $\left(\mathrm{CaCl}_{2}\right)$ : 4.7; potassium: $0.25 \mathrm{cmol}_{\mathrm{c}} \mathrm{dm}^{-3}$; calcium: 
$1.3 \mathrm{cmol}_{\mathrm{c}} \mathrm{dm}^{-3}$; magnesium: $1.1 \mathrm{cmol}_{\mathrm{c}} \mathrm{dm}^{-3}$; aluminum: $0.2 \mathrm{cmol}_{\mathrm{c}} \mathrm{dm}^{-3}$; hydrogen: $4.0 \mathrm{cmol}_{\mathrm{c}}$ $\mathrm{dm}^{-3}$; cation exchange capacity: $6.85 \mathrm{cmol}_{\mathrm{c}} \mathrm{dm}^{-3}$; base saturation: 39\%; phosphorus (resin): $11 \mathrm{mg}$ $\mathrm{dm}^{-3}$; and organic matter: $26 \mathrm{~g} \mathrm{dm}^{-3}$. To increase saturation to $70 \%$, dolomitic lime $(30 \% \mathrm{CaO}$ and $18 \% \mathrm{MgO}$ ) was applied the amount of $1.4 \mathrm{t} \mathrm{ha}^{-1}$.

Seeds of the TMG 11 WS genotype had used. In sowing was used $350 \mathrm{~kg} \mathrm{ha}{ }^{-1}$ of formulated mineral fertilizer N-P-K (04-30-10), and $130 \mathrm{~kg} \mathrm{ha}^{-1}$ of $\mathrm{N}$ were divided at 30 and 40 days after emergence, using urea as source.

In irrigated cultivation, a fixed sprinkler system was used, spacing $6 \times 6 \mathrm{~m}$ between them, with application intensity of $3.3 \mathrm{~mm} \mathrm{~h}^{-1}$. The volume of water applied was calculated using a class A tank, in order to obtain the reference evapotranspiration and using the crop coefficients, according to Allen et al. (1998). Irrigation had carried out until 120 days after emergence, when the crop had $70 \%$ of the bolls open.

Silicon applications had carried out using calcium silicate, foliar applications with a constant pressure costal spray, using model XR11002 nozzles with $2 \mathrm{~L}$ of volume and a pressure of 3.0 bar. The amount was divided into two applications, 50 and 70 days after plant emergence.

At 136 after emergence, bolls' harvest was carried out manually in the central plants (useful area). The material was sent to the fiber technology laboratory of the Sul Mato Grossense Association of Cotton Producers (AMPASUL), in Chapadão do Sul. Samples containing 20 bolls (from the middle third of the plant), from each experimental unit, were analyzed with the HVI equipment from Zellweger Uster/ Spinlab 900 series, the characteristics determined were, fiber length, length uniformity, maturation index, reliability index, spin consistency index, short fiber index, strength, reflectance, and degree of yellowing being determined.

Data were subjected to analysis of variance by the $\mathrm{F}$ test, and regression analysis for the amount of silicon.

\section{Results and discussion}

During the experiment period, the monthly rainfall accumulated in the initial months was greater than $250 \mathrm{~mm}$ (Table 1), and irrigation in the area was not often required, considering the demand for the crop and availability in the period (OLIVEIRA et al., 2013). Although in the subsequent months the accumulated rainfall reduced, values above $50 \mathrm{~mm}$ had observed, supplying a large proportion of the crop demand, which varies between 450 and $700 \mathrm{~mm}$ during the cycle (CARVALHO et al., 2013). In cotton crop, the maximum crop coefficient $(\mathrm{Kc})$ is obtained close to 60 days after sowing, and during the cycle it varies from 0.39 to 1.16 (OLIVEIRA et al., 2013).

Periods with water deficit is critical mainly in the reproductive phases, such as the development of buds, flowers and bolls (LIMA et al., 2018), however it has the potential to reduce the number of bolls per plant in different phenological phases (ALMEIDA et al., 2017).

Alterations related to resistance, reflectance and yellowing of the cotton fiber were significant only for the growing conditions (irrigated and not irrigated), while the leaf grade was significant for the application of Si (Table 2). 
Table 2. Summary of analysis of variance.

\begin{tabular}{cccccc}
\hline Cotton's characteristic & $\begin{array}{c}\text { Growing } \\
\text { conditions (C) }\end{array}$ & $\begin{array}{c}\text { Silicon } \\
(\mathrm{Si})\end{array}$ & C*Si & CV (\%) & Average \\
\hline Fiber length & $0.13^{\mathrm{ns}}$ & $0.66^{\mathrm{ns}}$ & $0.16^{\mathrm{ns}}$ & 2.30 & 27.61 \\
Micronaire & $0.06^{\mathrm{ns}}$ & $0.95^{\mathrm{ns}}$ & $0.41^{\mathrm{ns}}$ & 3.70 & 543.39 \\
Resistance & $0.05^{*}$ & $0.83^{\mathrm{ns}}$ & $0.96^{\mathrm{ns}}$ & 4.70 & 30.38 \\
Uniformity & $0.12^{\mathrm{ns}}$ & $0.67^{\mathrm{ns}}$ & $0.93^{\mathrm{ns}}$ & 1.14 & 82.24 \\
Fiber elongation & $0.11^{\mathrm{ns}}$ & $0.76^{\mathrm{ns}}$ & $0.68^{\mathrm{ns}}$ & 2.86 & 55.54 \\
Reflectance & $0.01^{* *}$ & $0.27^{\mathrm{ns}}$ & $0.26^{\mathrm{ns}}$ & 1.24 & 81.64 \\
Yellowing & $0.01^{* *}$ & $0.17^{\mathrm{ns}}$ & $0.84^{\mathrm{ns}}$ & 5.40 & 6.84 \\
Leaf grade & $0.13^{\mathrm{ns}}$ & $0.04^{*}$ & $0.54^{\mathrm{ns}}$ & 59.71 & 1.58 \\
Impurity & $0.19^{\mathrm{ns}}$ & $0.06^{\mathrm{ns}}$ & $0.57^{\mathrm{ns}}$ & 74.13 & 17.00 \\
Impurity particles & $0.59^{\mathrm{ns}}$ & $0.25^{\mathrm{ns}}$ & $0.89^{\mathrm{ns}}$ & 46.14 & 8.21 \\
\hline
\end{tabular}

$\mathrm{ns},{ }^{*}$ and ${ }^{* *}$ : not significant, $5 \%$ significant and $1 \%$ significant by the $\mathrm{F}$ Test, respectively.

Irrigation should be adopted in order to suppress demand in periods of deficit in order to allow the crop to perform maximum productive potential and commercial quality (SANTOS et al., 2018), and the increase in soil moisture benefits the development of morphological and yield components (OLIVEIRA et al., 2012).
Adequate water conditions are also fundamental for efficient fertilizer management, such as nitrogen application (BORIN et al., 2017). Growing irrigated cotton under the study conditions increased fiber strength and reflectance (Table 3).

Table 3. Influence of water availability on cotton fiber characteristics.

\begin{tabular}{cccc}
\hline Cotton's characteristic & Irrigated & Not irrigated & MSD $^{(1)}$ \\
\hline Fiber length (mm) & $27.73 \mathrm{a}$ & $27.48 \mathrm{a}$ & 32.89 \\
Micronaire & $549.12 \mathrm{a}$ & $537.67 \mathrm{a}$ & 11.82 \\
Resistance $\left(\right.$ gf text $^{-1}$ ) & $30.80 \mathrm{a}$ & $29.96 \mathrm{~b}$ & 8.39 \\
Uniformity (\%) & $82.45 \mathrm{a}$ & $82.02 \mathrm{a}$ & 5.51 \\
Fiber elongation (\%) & $55.17 \mathrm{a}$ & $55.92 \mathrm{a}$ & 0.93 \\
Reflectance (\%) & $82.38 \mathrm{a}$ & $80.90 \mathrm{~b}$ & 5.95 \\
Yellowing (+b) & $6.70 \mathrm{~b}$ & $6.99 \mathrm{a}$ & 2.17 \\
Leaf grade & $1.79 \mathrm{a}$ & $1.37 \mathrm{a}$ & 0.55 \\
Impurity (\%) & $15.00 \mathrm{a}$ & $19.00 \mathrm{a}$ & 0.07 \\
Impurity particles & $7.92 \mathrm{a}$ & $8.50 \mathrm{a}$ & 2.22
\end{tabular}

*Different letters in the same line differ from each other. ${ }^{(1)} \mathrm{MSD}$-minimum significant difference.

Short periods of drought are enough to limit carbohydrate translocation to cotton fruits, negatively affecting micronaire characteristics and fiber strength (ECHER et al., 2018), justifying lower resistance in non-irrigated conditions. 
In the irrigated condition, the reflectance was higher and the yellowing was lower (Table 3), which is a positive point considering that the values can vary with a decrease in quality due to storage (LIMA et al., 2009), and directly influencing the commercial value of the product.

Fiber quality characteristics are affected by environmental conditions such as temperature, light and shading, but the impact of each factor on final quality is variable by genetic conditions (ECHER et al., 2018; BONIFÁCIO et al., 2015). The fibers obtained in the study showed high quality for use in the textile industry, mainly because of their excellent fiber length $(>25 \mathrm{~mm})$ and uniformity (>47\%) (SANTANA; WANDERLEY, 1995).

Regarding the application of $\mathrm{Si}$, studies demonstrate the benefits of using it in cotton cultivation, with significant results in the seed growth rate, in the case of seed (FERRAZ et al., 2017), and in fiber quality characteristics such as reflectance, short fiber index, micronaire and yellowing (GAMA et al., 2016). It also can be adopt as a pest management strategy (ALCANTRA et al., 2019), in addition to improve morphological development and yield under water deficit conditions (WENNECK et al., 2021).

In the study, the application of $\mathrm{Si}$ was significant $(p<0.05)$ only for the variable leaf grade (Table 2 ), which is an analysis parameter for the presence of impurities in the fiber. Under experimental conditions, $\mathrm{Si}$ reduced the leaf grade (Figure 1), increasing the commercial quality of the product.

Figure 1. Influence of Silicon foliar applications on leaf grade in cotton fibers.

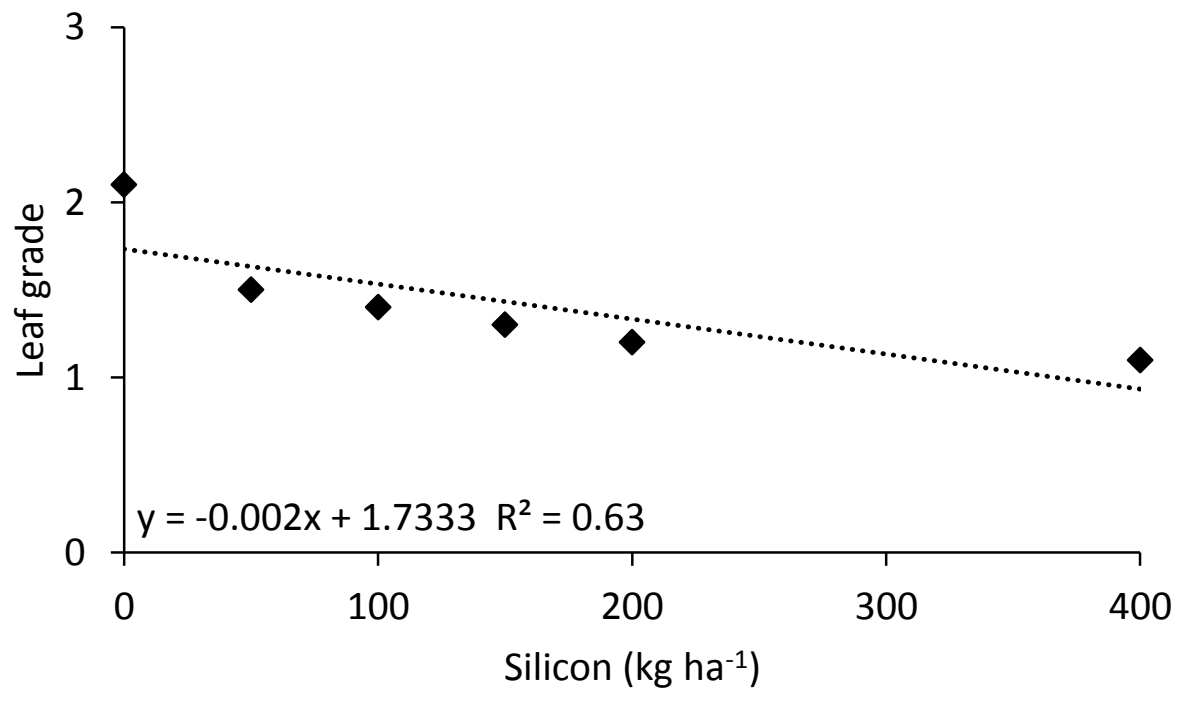

Silicon has benefits on yield and quality in several crops, especially in unfavorable physical and chemical conditions, but the impact varies with the content of the element in the soil, plant species, source and form of application (MALAVOLTA, 2006). Foliar applications, in general, are more efficient due to lower cost and rapid absorption, however fertilization efficiency can be affected by environmental factors (GONÇALVES et al., 2017).

However, genetic characteristics associated with response to $\mathrm{Si}$ application must be considered. Ferraz (2012) when analyzing the foliar silicon application (dose up to $200 \mathrm{~g} \mathrm{ha}^{-1}$ ) in different cotton cultivars obtained different results among the analyzed cultivars. Although studies with $\mathrm{Si}$ application in the material used
(TMG 11 WS) are limited, the inexistence of significant effects for doses used can indicate that the cultivar isn't responsive to silicate fertilization.

Technological quality increments in cotton fiber have the potential to improve the commercial characteristics of the product, justifying the adoption of water management practices and silicate fertilization, however, an economic analysis is necessary to determine the cost/benefit ratio of the increment caused.

\section{Conclusions}

Under the growing conditions of this study, the cotton crop is more responsive to the water deficit condition than to silicon doses. 
Cotton fiber in irrigated cultivation show improvement in resistance, reflectance and yellowing characteristics.

The application of $\mathrm{Si}$ reduce the leaf grade in the cotton fibers.

\section{Acknowledgment}

To the Coordenação de Aperfeiçoamento de Pessoal de Nível Superior - Brasil (Capes) and the Conselho Nacional de Desenvolvimento Científico e Tecnológico (CNPq).

\section{References}

ALCANTRA, E.; MORAES, J. C.; AUAD, A. M.; SILVA, A. A.; ALVARENGA, R. Resistência induzida ao pulgão-do-algodoeiro em cultivares de algodão colorido. Revista de Ciências Agrárias, v.42, n.2, p.483-491, 2019. https://doi.org/10.19084/rca.17183.

ALMEIDA, E. S. A. B.; PEREIRA, J. R.; AZEVEDO, C. A. V.; ARAÚJO, W. P.; ZONTA, J. H.; CORDÃO, M. A. Algodoeiro herbáceo submetido a déficit hídrico: produção. Agropecuária Científica no Semiárido, v.13, n.1, p.22-28, 2017.

BORIN, A. L. D. C.; FERREIRA, A. C. B.; SOFIATTI, V.; CARVALHO, M. C. S.; MORAES, M. C. G. Produtividade do algodoeiro adensado em segunda safra em resposta à adubação nitrogenada e potássica. Revista Ceres, v.64, n.6, p.622-630, 2017. https://doi.org/10.1590/0034737X201764060009.

CARVALHO, I. R.; KORCELSKI, C.; PELISSARI, G.; HANUS, A. D.; ROSA, G. M. Demanda hídrica das culturas de interesse agronômico. ENCICLOPÉDIA BIOSFERA, v.9, n.17, p.969-985 2013.

CAVAlCANTE, A. U. M.; TANNúS, S. P. Competitividade da cotonicultura em países selecionados. Revista Competitividade e Sustentabilidade, v.7, n.3, p.638-652, 2020. https://doi.org/10.48075/comsus.v7i3.24665.

ECHER, F.; ROSOLEM, C. A.; RAPHAEL, J. P. A. Manual de qualidade da fibra. AMPA - IMAmt, $2018 . \quad$ Disponível em: unoeste.br/site/cursoposgraduacao/documentos /agronomia/2020/2019\%20manual_qualidade_p arte4.pdf.

FEIS/UNESP. Dados climáticos da estação de Selvíria-MS. Disponível em: http://clima.feis.unesp.br/. Acesso em: 25 jan. 2021.

FERRAZ, R. L. S. Crescimento, fisiologia e produção do algodoeiro sob efeito do silício via foliar. 2012. Dissertação (Mestrado em Ciências Agrárias) - Centro de Ciências Humanas e Agrárias, Universidade Estadual da Paraíba, 2012.

FERRAZ, R. L. S.; BARBOSA, M. A.; MAGALHÃES, I. D.; MELO, A. S.; ROCHA, M. S.; COSTA, P. S. Atributos qualitativos de sementes de algodoeiro hidrocondicionadas em soluções de silício. Científica, v.45, n.1, p.85-94, 2017. http://dx.doi.org/10.15361/19845529.2017v45n1p85-94

GAMA, J. S. N.; PEREIRA JUNIOR, L. R., PEREIRA, F. J. S.; OLIVEIRA, E. L.; CAMPOS, D. A.; BARROS, A. C. S. A. Efeito da adubação silicatada na qualidade da fibra do algodoeiro. Magistra, v.28, n.2, p.244-253, 2016.

LIMA, A, K. V. O.; DUARTE, S. M. A.; SILVA, L. Caracterização da reflectância e grau de amarelamento da fibra do algodão BRS 200 Marrom armazenada. Revista de Biologia e Ciências da Terra, v.9, n.2, p.182-186, 2009.

LIMA, R. F.; ARAÚJO, W. P.; PEREIRA, J. R.; CORDÃO, M. A.; FERREIRA, F. N.; ZONTA, J. H. Fibras de algodoeiro herbáceo sob déficit hídrico. Revista Verde de Agroecologia e Desenvolvimento Sustentável, v.13, n.4, p.427436, $2018 . \quad$ DOI: http://dx.doi.org/10.18378/rvads.v13i4.5940.

MALAVOLTA, E. Manual de nutrição mineral de plantas. São Paulo: Agronômica Ceres, 2006. 638p.

MORAIS, J. P. S.; FARIAS, F. J. C.; BELOT, J. L.; MARTINS, R. S. A.; MIZOGUCHI, E. T. Interpretação das características avaliadas no SITC para qualidade de fibra de algodão - Uma abordagem prática. Campina Grande: Embrapa Algodão, 2021. 46p.

OLIVEIRA, S. R. M.; ANDRADE JÚNIOR, A. S.; RIBEIRO, J. L.; BARROS, M. A. Coeficientes de cultura do algodão herbáceo e do feijão-caupi em sistemas monocultivo e consorciado. Revista Brasileira de Agricultura Irrigada v.7, n. 3, p.191- 
200,

2013.

https://doi.org/10.7127/rbai.v7n300015

OLIVEIRA, S. R. M.; ANDRADE JÚNIOR, A. S.; RIBEIRO, V. Q.; MORAIS, E. L. C. Desempenho produtivo do algodão em monocultivo e consorciado com feijão-caupi em resposta à disponibilidade hídrica no solo. Comunicata Scientiae, v.3, n.4, p.282-291, 2012.

SANTANA, J. C. F.; WANDERLEY, M. J. R. Interpretação de resultados de análises de fibras efetuadas pelo instrumento de alto volume (HVI) e pelo finurímetro-maturímetro (FMT2). Campina Grande: EMBRAPA-CNPA, 1995. 9 p.

SANTOS, G. O.; VANZELA, L. S.; FARIA, R. T. Manejo da Água na Agricultura Irrigada. Boletim Técnico. Associação Brasileira de Engenharia Agrícola, v.1, n.1, p.1-40, 2018.

WENNECK, G. S.; SAATH, R.; REZENDE, R.; ANDREAN, A. F. B. A.; SANTI, D. C. Agronomic response of cauliflower to the addition of silicon to the soil under water deficit. Pesquisa Agropecuária Tropical, v.51, e66908, 2021. https://doi.org/10.1590/1983-

\section{5v28n405rc}

ZONTA, J. H.; BEZERRA, J. R. C.; SOFIATTI, V.; FARIAS, F. J. C.; CARVALHO, L. P. Efeito da irrigação no rendimento e qualidade de fibras em cultivares de algodoeiro herbáceo. Revista Caatinga, v.28, n.4, p.43-52, 2015. 